\title{
THE CORPORATE GOVERNANCE ROLE OF LENDERS: MINORITY SHAREHOLDERS CHAMPIONS?*
}

\section{EL ROL EN EL GOBIERNO CORPORATIVO DE LOS BANCOS: ¿PROTECTORES DE LOS ACCIONISTAS MINORITARIOS?}

\author{
Santiago Miramón-Botero*** \\ Reception date: January 25, 2017 \\ Acceptance date: March 20, 2017 \\ Available online: November 30, 2017
}

\section{To cite this article/Para citar este artículo}

Miramón-Botero, Santiago, The Corporate Governance Role of Lenders: Minority Shareholders Champions?, 135 Vniversitas, 219-254 (2017). https:// doi.org/10.11144/Javeriana.vj135.cgrl

doi:10.11144/Javeriana.vj135.cgrl

* This article is the author's dissertation for obtaining the LL.M. degree in Corporate and Securities Law in The London School of Economics and Political Science. The dissertation was chosen as LLM Sample Dissertation Model by the Law Department.

** Attorney from the Pontificia Universidad Javeriana. Specialist in Contracts and Business Relations from the Universidad Externado de Colombia. Master (LL.M.) in Corporate and Securities Law from The London School of Economics and Political Science. Orcid: 0000-0002-6010-9759. Contact: santiago.miramon@gmail.com 


\section{ABSTRACT}

The purpose of this research is to determine if the supervision of non-listed and non-financially distress companies by creditors in the United Kingdom helps to overcome the controlling shareholder agency problem, and if as a by-product of this supervision, minority shareholders are better protected by the creditors than by the incumbent legal framework in the United Kingdom (UK).

Keywords: Majority-minority shareholders agency problem; lender governance; loan agreements; UK Company Law 


\section{RESUMEN}

El objetivo de este artículo es determinar si la supervisión de las compañías (no cotizantes en el mercado público de valores y sin problemas de liquidez) por parte de los bancos en el Reino Unido ayuda a superar el problema de la agencia entre los accionistas mayoritarios y minoritarios, y si como consecuencia de esta supervisión los accionistas minoritarios están mejor protegidos por los bancos que por el marco regulatorio vigente en el Reino Unido sobre la protección de accionistas minoritarios

Palabras clave: Problema de agencia entre accionistas mayoritarios y minoritarios; contratos de mutuo; bancos como administradores sociales; legislación societaria de Reino Unido

\section{SUMMARY}

Introduction.- I. The Agency Problems.- A. Borrower-Lender Agency Problem.- B. Controlling Shareholders Agency Problem.- II. Methods TO ADDRESS THE AGENCY PRoblems AND THEIR EFFiCACY.- $A$. Contractual Protection and Security Interest.- B. Minority Shareholder Protection in United Kingdom's Company Law.- III. LOAN AGREEMENT EXTERnAlTIES.- A. Protection and Incentives Created by the Loan Agreement.- B. UK Company Law v. Loan Agreements.- IV. Drawbacks of LENDERS supervision.- A. Dividend Restriction Covenants.- B. Debt Decoupling.CONCLUSION.- BibliogRAPHY. 


\section{INTRODUCTION}

Many people often see banks as greedy institutions who act against their client interests and whose business is to take other people's money in order to pay huge salaries to their CEOs. ${ }^{1}$ Indeed, banks have been compared with a 'body of water' as 'there is far more to them than what we see on the surface, they often contain odd and savage creatures, from which most people are better off keeping a distance, and ultimately, they can give life or inflict death, depending on their mood. In fact, it seems the only thing water and banks do not share is transparency'. ${ }^{2}$ Nevertheless, has someone ever questioned the social welfare created by the bank industry? This poor reputation, sometimes accurately earned, does not reflect the full scope of the actual role played by banks (lenders) in modern society, where they provide the means needed by firms to create jobs, goods and services that benefit society as a whole. Moreover, as will be demonstrated, the supervision of lenders over their borrowers increases the value of those firms and ultimately prevents abusive behaviour from their controlling shareholders (CS), transforming lenders into the minority shareholders' (MS) champions. The corporate governance role of lenders, ${ }^{3}$ and how it increases the value of companies ${ }^{4}$ has been seldom analysed in the last few years. However, a few remarks have been made about the way in which 'lenders governance' influences the CS agency problem. Likewise, the study of how the interests of shareholders tends to align under the supervision of lenders has been ancillary

1 See Barack Obama, President of the United States of America. President Barack Obama, Remarks of President Barack Obama (Address to Joint Session of Congress, February 24, 2009). Available at: https://obamawhitehouse.archives.gov/the-press-office/remarks-president-barack-obama-addressjoint-session-congress

2 Neill O’Neill, Sadly, Banks Are a Necessary Evil, The Mayo News [July 24, 2012]. Available at: http://www.mayonews.ie/comment-opinion/68-off-the-fence/15790-sadly-banks-are-a-necessaryevil

3 Georges G. Triantis \& Ronald J. Daniels, The Role of Debt in Interactive Corporate Governance, 83 University of California Law Review, 4, 1073-1113 (1995). Available at: http://scholarship.law. berkeley.edu/cgi/viewcontent.cgi?article $=1669 \&$ context $=$ californialawreview

4 Joanna M. Shepherd, Frederick Tung \& Albert H. Yoon, What Else Matters for Corporate Governance?: The Case of Bank Monitoring, 88 Boston University Law Review, 4, 991-1041 (2008). Available at: http://www.bu.edu/law/journals-archive/bulr/volume88n4/documents/yoon-whatelsematters.pdf

5 Frederick Tung, Leverage in the Board Room: The Unsung Influence of Private Lenders in Corporate Governance, 57 UCLA Law Review, 115-181 (2009). Available at: http://www.uclalawreview.org/ pdf/57-1-3.pdf 
to the overall study of how the lenders' oversight diminishes managerial discretion, benefiting the shareholders as a whole. ${ }^{6}$ Therefore, the purpose of this research is to determine if the supervision of non-listed and non-financially distressed companies by lenders in the UK helps to overcome the CS agency problem, and if as an externality of this supervision, MS are better protected by lenders than by the incumbent legal framework in the UK.

Section I of the research will consider two agency problems: (i) between the company (borrower) and the lender, and (ii) between CS and MS. In addition, credit risk implied in the loan agreement (LA), as well as the agency problem that it originates, will be briefly addressed. Likewise, the interests of the shareholders as two different constituencies (CS and MS) will be examined. In particular, this section will focus on the how interests of shareholders tend to collide as a consequence of the "private benefits of control' ${ }^{77}$ gained by CS at the cost of MS.

In Section II of this article, we will analyse how these two agency problems are tackled in general, and the efficacy of the measures taken to address these difficulties. Consequently, we will scrutinise the main contractual tools that lenders use to mitigate the credit risk when furnishing finance to borrowers, covenants and events of default clauses included in the loan agreements ${ }^{8}$ (LA) as well as security interests. In the same way, we will explore the protection mechanisms given by UK company law to MS, specially the derivative and unfair prejudice claims, and their efficacy to protect MS.

Section III of the research will explore the externalities created by the LA affecting MS and CS. Hence, the incentives that these agreements create between lenders and borrowers will be scrutinised, aiming to determine how the CS agency problem is swayed by them; and thus, if the overall incentives created benefit the MS and provide more effective protection against $\mathrm{CS}$ abuses than the actual minority protection statutory framework.

6 Frederick Tung, Leverage in the Board Room: The Unsung Influence of Private Lenders in Corporate Governance, 57 UCLA Law Review, 115-181 (2009).

7 Luca Enriques \& Paolo Volpin, Corporate Governance Reforms in Continental Europe, 21 Journal of Economic Perspectives, 1, 117-140 (2007). Available at: https://papers.ssrn.com/sol3/papers. cfm?abstract_id $=970796$

8 Louise Gullifer \& Jennifer Payne, Corporate Finance Law: Principles and Policy ( $2^{\text {nd }}$ ed., Hart Publishing, Oxford, 2015). 
Finally, Section IV will examine the possible drawbacks caused by lenders' oversight, in particular the restriction they impose on the dividends to be distributed by the company, ${ }^{9}$ and the problems concerning the transference of the credit risk away from lenders' books using credit default swaps. ${ }^{10}$ However, as will be explained, the downsides of lenders' supervision are apparent and lenders still have incentives to supervise the borrower.

\section{THE AGENCY PROBLEMS}

Despite the lack of consensus about the exact origin and authorship of the agency theory, ${ }^{11}$ it became so important for the social sciences that the different problems arising from its study have been analysed from countless perspectives over the last 50 years. ${ }^{12}$ However, is commonly agreed that, in an economic sense, there is an agency relationship when the welfare of one person (principal) depends on the acts of another person (agent), who has some degree of authority or discretion to perform on behalf of the former (principal). ${ }^{13}$ Consequently, the problem of the agency relationship lies in the fact that the agent will not always act in the best interest of the principal. ${ }^{14}$ This behaviour might be caused, inter alia, by a misalignment of the interests of both parties ${ }^{15}$ or by information asymmetries that allow the agent to behave 'opportunistically.' ${ }^{16}$

9 Louise Gullifer \& Jennifer Payne, Corporate Finance Law: Principles and Policy (2 ${ }^{\text {nd }}$ ed., Hart Publishing, Oxford, 2015).

10 Yesha Yadav, The Case for a Market in Debt Governance, 67 Vanderbilt Law Review, 3, 771-835 (2014). Available at: https://papers.ssrn.com/sol3/papers.cfm?abstract_id=2225524

11 Cf. Barry M. Mitnick, Origin of the Theory of Agency: An Account by One of the Theory's Originators (March 25, 2013). Available at: http://ssrn.com/abstract $=1020378$

12 Barry M. Mitnick, Origin of the Theory of Agency: An Account by One of the Theory's Originators, 3-10 (March 25, 2013). Available at: http://ssrn.com/abstract $=1020378$

13 Michael C. Jensen \& William H. Meckling, Theory of the Firm: Managerial Behaviour, Agency Costs and Ownership Structure, 3 Journal of Financial Economics, 4, 305-360 (1978). Available at: https://www2.bc.edu/thomas-chemmanur/phdfincorp/MF891\%20papers/Jensen\%20and\%20 Meckling\%201976.pdf

14 Michael C. Jensen \& William H. Meckling, Theory of the Firm: Managerial Behaviour, Agency Costs and Ownership Structure, 3 Journal of Financial Economics, 4, 305-360 (1978).

15 Michael C. Jensen \& William H. Meckling, Theory of the Firm: Managerial Behaviour, Agency Costs and Ownership Structure, 3 Journal of Financial Economics, 4, 305-360 (1978).

16 Reinier Kraakman, John Armour, Paul Davies, Luca Enriques, Henry Hansmann, Gerard Hertig, Klaus Hopt, Hideki Kanda, Mariana Pargendler, Wolf-Georg Ringe \& Edward Rock, The Anatomy of Corporate Law. A Comparative and Functional Approach $\left(2^{\text {nd }}\right.$ ed., Oxford University Press, Oxford, 2009). 
As can be inferred, the above mentioned agency problem analysis can be applied to myriad commercial and labour relationships. Therefore, this research will focus only on the agency problems that arise from: (i) the relationship between lenders and borrowers when a LA is entered; and (ii) to the relationship between CS and MS of a company.

\section{A. Borrower-Lender Agency Problem}

LA are usually the outcome of lengthy negotiations between lenders and borrowers, lenders main purpose is to assess the creditworthiness of a potential borrower, and thus the risk of no repayment. Accordingly, if the result of the assessment is that the credit risk is not abnormal, the lender will set a price for lending the resources (interest rate) that cover the risks assumed in the operation, and lend the capital. This means that, once the resources have been given to the borrower, the lender will expect the borrower's creditworthiness to remain stable, and that the borrower will not act in a way that could undermine his value and therefore the ability to repay the debt. ${ }^{17}$ The borrower will try to demonstrate a low risk of non-repayment during the lenders' assessment in order obtain financing and avoid high interest rates.

However, once the LA is entered, borrowers have no incentives to maintain their risk profile as they have secured the resources and, unless they had agreed on a revolving credit facility, borrowers will not have to meet any further commitments for future drawdowns. ${ }^{18}$ Moreover, far from purporting to keep the risk status of the company, shareholders, even when the company is in good financial shape, have incentives to pursue risky undertakings. Shareholders' welfare increases if the value of the company also increases; hence shareholders (in a practice commonly known as 'overinvestment') pressure directors to seek riskier projects with higher returns, even though the probability of a successful outcome is limited. Another

17 Louise Gullifer \& Jennifer Payne, Corporate Finance Law: Principles and Policy, $22-27$ (2 ${ }^{\text {nd }}$ ed., Hart Publishing, Oxford, 2015).

18 For the discussion about whether a bank is committed to provide funding, see ANDREw McKNIGHT, Commitments to Lend in Troubled Times, 3 Law and Financial Markets Review, 2, 148-154 (2009). 
common agency problem that arises after the entering of the LA is the 'asset dilution'. This method consists of distributing the company's assets amongst shareholders by 'payment of dividends or the repurchase of stock'. ${ }^{19}$

On the other hand, though the so-called 'managerial agency problem' will not be addressed in this research, managers can act in their own interests and not in the company's. Hence, managers can reduce the company's value ${ }^{20}$ by transferring value from the company to themselves (i.e. self dealing, management remuneration or corporate opportunities); ${ }^{21}$ by reducing the company's value with its inaction ('shirking and incompetence'); ${ }^{22}$ wasting corporate resources on 'perquisites ${ }^{23}$ or feeding their ego ('hubris'). ${ }^{24}$ These practices can lead to a change in the company's creditworthiness and its value, and may harm its ability to repay its debt.

Consequently, an agency problem arises after the LA is entered, as the welfare of the lender (principal) depends on the acts and behaviour of the borrower (agent). ${ }^{25}$ Nevertheless, this moral hazard is well known in the financial services industry where an array of protective measures have been developed to reduce the credit risk and to give early warnings to the lender when the borrower's creditworthiness deteriorates.

\section{B. Controlling Shareholders Agency Problem}

In the UK, listed companies are widely held, ${ }^{26}$ hence the managerial agency problem described briefly above should be especially

19 Georges G. Triantis, Secured Debt under Conditions of Imperfect Information, 21 The Journal of Legal Studies, 1, 225-258 (1992).

20 For an example of extreme value destruction caused by managers, see United Kingdom, Court of Appeal, Re Barings PLC and others (No 5) [1999] 1 BCLC 433 (Chancery Division).

21 David Kershaw, Company Law in Context: Text and Materials (2 ${ }^{\text {nd }}$ ed., Oxford University Press, Oxford, 2012).

22 David Kershaw, Company Law in Context: Text and Materials, 178 ( $2^{\text {nd }}$ ed., Oxford University Press, Oxford, 2012).

23 David Kershaw, Company Law in Context: Text and Materials, 178 (2 $2^{\text {nd }}$ ed., Oxford University Press, Oxford, 2012).

24 David Kershaw, Company Law in Context: Text and Materials, 179 ( $2^{\text {nd }}$ ed., Oxford University Press, Oxford, 2012).

25 For the analysis of this problem regarding bondholders instead of lenders, see Clifford W. SMith \& Jerold B. Warner, On Financial Contracting: An Analysis of Bond Covenants, 7 Journal of Financial Economics, 2, 117-161 (1979).

26 Rafael La Porta, Florencio López-de-Silanes \& Andrei Shleifer, Corporate Ownership around the World, 54 The Journal of Finance, 2, 471-517, Table II (1999). 
relevant for this study. Still, as this article centres on non-listed companies, which have 'concentrated ownership with high management-ownership overlap ${ }^{27}$ the focus on the controlling agency problem seems to be an appropriate approach.

MS and CS interests are not invariably aligned; therefore several agency problems can arise when their interests take separate ways. However, apart from the 'blocking minority' agency problem ${ }^{28}$ there is a second and more relevant agency problem from our study known as the 'controlling shareholder agency problem'. Here, the CS (agent) use their power to favour their own interests at the expense of the MS (principal). Accordingly, this imbalance creates a gap in the company's value, known as the private benefits of control, ${ }^{29}$ whereby the more benefits the CS can extract from the corporate assets for themselves, the more valuable their participation becomes against the other shareholders' participation. ${ }^{30}$ Therefore, the CS have many methods to extract those benefits from the company and transfer them to another company in which they have a bigger (or the sole) participation; or use the assets for their own personal benefit, excluding the other shareholders.

The methods used by CS to 'expropriate' the other shareholders along with the fashion in which UK law addresses this problem will be analysed in the next section.

\section{METHODS TO ADDRESS THE AGENCY PROBLEMS AND THEIR EFFICACY}

The above-mentioned agency problems are not new, and though lawmakers and courts have addressed both problems, the approaches have been different. On one hand, in the lender-borrower

27 Tony Buxton, Paul Chapman \& Paul Temple, Britain's Economic Performance (Routledge, London, 2005).

28 John Armour, Henry Hansmann \& Reinier Kraakman, Agency Problems and Legal Strategies, in The Anatomy of Corporate Law. A Comparative and Functional Approach, 29-48, 36 (2 $2^{\text {nd }}$ ed., Reinier Kraakman, John Armour, Paul Davies, Luca Enriques, Henry Hansmann, Gerard Hertig, Klaus Hopt, Hideki Kanda, Mariana Pargendler, Wolf-Georg Ringe \& Edward Rock, Oxford University Press, Oxford, 2009).

29 For a further investigation on the different types of benefits for private control, see EDMUND PHILIPP Schuster, The Mandatory Bid Rule: Efficient, After All?, 76 Modern Law Review, 3, 529-563 (2013).

30 Luca Enriques \& Paolo Volpin, Corporate Governance Reforms in Continental Europe, 21 Journal of Economic Perspectives, 1, 117-140, 122-123 (2007). 
agency problem the lenders are seen as 'adjusting creditors' ${ }^{31}$ who can adjust the terms in which they agree to lend to a particular borrower at a particular time, in order to reflect the risks taken in the transaction. ${ }^{32}$ As a consequence, the law leaves these types of creditors to protect themselves from the agency costs through, inter alia, contractual arrangements and security interests. ${ }^{33}$ On the other hand, some authors may argue that the private benefits of control earned by $\mathrm{CS}$ are a fair consideration for their monitoring role of the company. ${ }^{34}$ Moreover, it is argued that MS can bargain their protection with CS through shareholders' agreements or constitution amendments. ${ }^{35}$ However, it is commonly agreed that some level of statutory investor protection must be granted to MS, in particular, as not doing so will create a perverse incentive for investors to buy blocks of shares in order to exploit the private benefits of control $^{36}$ and will force new investors, with no bargaining power, to discount the price of the shares, increasing the cost of raising capital by companies. ${ }^{37}$

\section{A. Contractual Protection and Security Interest}

In Section I.A the different agency problems that a lender might have to face after a LA is entered were considered. Likewise, it was pointed out that this agency problem could materialise in, amongst others, three different actions or behaviours: (i) overinvestment; (ii) asset dilution, and (iii) opportunistic behaviour of the borrower's

31 Lucian Ayre Bebchuk \& Jesse M. Fried, The Uneasy Case for the Priority of Secured Claims in Bankruptcy, 105 The Yale Law Journal, 857-934 (1996). Available at: http://www.law.harvard.edu/ faculty/bebchuk/pdfs/tylj.96.bebchuk-fried.pdf, https://papers.ssrn.com/sol3/papers.cfm?abstract_ $\mathrm{id}=417960$. Though a lender with a security interest can be seen as a secured creditor and not as an adjusting (unsecured) creditor in the terms used by the authors.

32 Lucian Ayre Bebchuk \& Jesse M. Fried, The Uneasy Case for the Priority of Secured Claims in Bankruptcy, 105 The Yale Law Journal, 857-934, 885 (1996).

33 Louise Gullifer \& Jennifer Payne, Corporate Finance Law: Principles and Policy, 83 (2 ${ }^{\text {nd }}$ ed., Hart Publishing, Oxford, 2015).

34 Paul L. Davies, Gower and Davies': The Principles of Modern Company Law $\left(8^{\text {th }}\right.$ ed., Sweet \& Maxwell, London, 2008).

35 David Kershaw, Company Law in Context: Text and Materials, 649-650 (2 ${ }^{\text {nd }}$ ed., Oxford University Press, Oxford, 2012).

36 David Kershaw, Company Law in Context: Text and Materials, 647 (2 ${ }^{\text {nd }}$ ed., Oxford University Press, Oxford, 2012).

37 Paul L. Davies, Gower and Davies': The Principles of Modern Company Law, 686 ( $8^{\text {th }}$ ed., Sweet \& Maxwell, London, 2008). 
managers. ${ }^{38}$ Hence, we will now analyse how lenders address these three behaviours when crafting the LA and the efficacy of the measures therein adopted.

The first mechanism that can be adopted is to include covenants in the LA, which are obligations that borrowers have to honour during the whole term of the agreement. These usually aim either to require borrowers to constantly send information to lenders; to restrain borrowers from disposing of their assets; or to oblige borrowers to meet some financial ratios. ${ }^{39}$ In the first category, the most common are information covenants, which are contained by default in standardised LA. Information covenants require borrowers to send a vast array of financial information to the lenders, including their financial statements, and to notify the lender of any default. ${ }^{40}$ Similarly, other covenants may impose restrictions on the borrowers' activities and thus, borrowers will require lenders' authorization before effecting a merger, a change of business, or before disposing of assets other than in the 'ordinary course of trading ${ }^{9}{ }^{41}$ Moreover, it is not rare for a LA to include restrictions on the amount in which dividends can be paid to the borrowers' shareholders. Nevertheless, it is important to bear in mind that these financial covenants can be tailored in a fashion that reflects the risk taken by the lender, the likelihood of repayment and the likelihood of misbehaviour on the side of the borrower. ${ }^{42}$ Therefore, though it is impossible to anticipate all the potentially harmful behaviours of a borrower, they provide an important defensive tool for reducing credit risk.

The importance of covenants is that, their breach triggers an 'event of default, ${ }^{43}$ which allow the lender to terminate the contract

38 The borrowers can have other types of misbehaviour, nevertheless other acts such as 'underinvestment' or devaluating the existing debt by issuing new, better ranking debt are more likely in insolvency scenarios or in unsecured lending so they will not be addressed in this article. However, for further borrower misbehaviour, see Georges G. TRiantis, Secured Debt under Conditions of Imperfect Information, 21 The Journal of Legal Studies, 1, 225-258, 235-238 (1992).

39 Louise Gullifer \& Jennifer Payne, Corporate Finance Law: Principles and Policy, 195 (2 ${ }^{\text {nd }}$ ed., Hart Publishing, Oxford, 2015).

40 Loan Market Association, Single Currency Term and Revolving Facilities Agreement (LMA.STR08) 2014, clauses 19-21.

41 Loan Market Association, Single Currency Term and Revolving Facilities Agreement (LMA.STR08) 2014, clauses 21.4-21.6.

42 Loan Market Association, Single Currency Term and Revolving Facilities Agreement (LMA.STR08) 2014, clauses 21.4-21.6.

43 Loan Market Association, Single Currency Term and Revolving Facilities Agreement (LMA.STR08) 2014, clauses 22.3-22.3. But events of default are much wider than a breach of contract and can be 
and accelerate the repayment obligation, could also give rise to other events of default when there are cross default clauses in other agreements. They might thus drag the borrower into insolvency. ${ }^{44}$ Furthermore, if covenants are coupled with a security interest in the form of a 'qualifying floating charge', ${ }^{45}$ the event of default can be a 'crystallising event' that gives lenders the power to appoint an administrator to manage the company and dispose of its assets in order to rescue the company or wind it up. ${ }^{46}$

The combinations of these three techniques, along with an adequate level of supervision on the lender side, are an effective deterrent against misbehaviours of borrowers. Well-drafted contracts can prevent overinvestment and asset dilution, as covenants may require lenders' approval for most of the borrower's activities and compliance with some financial ratios that may also prevent borrowers from taking excessive debts or venturing into new, risky business. ${ }^{47}$ Furthermore, the threat of default can be quite persuasive to replace top managers or directors if they misbehave, making this mechanism even better suited to address the managerial agency problem than some company laws. ${ }^{48}$

However, the effects that this 'lender monitoring' can have on the behaviour of the CS, and whether the MS are better protected against eventual CS expropriations through these LA than by UK company law will be considered in the next section.

triggered by situations out of the borrower's control such as its insolvency (clause 22.6); cross-default (clause 22.5), or a material adverse change (clause 22.12).

44 Louise Gullifer \& Jennifer Payne, Corporate Finance Law: Principles and Policy, 213-214 (2 ${ }^{\text {nd }}$ ed., Hart Publishing, Oxford, 2015).

45 United Kingdom, Insolvency Act 1986, Sch B1 para. 14(2). Available at: http://www.legislation.gov. uk/ukpga/1986/45/pdfs/ukpga_19860045_en.pdf

46 JennifER PAYne, Debt Restructuring in English Law: Lessons from the US and the Need for Reform, 13 (Oxford Legal Research Paper Series 89/2013, 2014). Available at: http://ssrn.com/abstract=2321615

47 For an in depth comparison between the effectiveness and efficiency of the covenants and the security interest, see Lucian Ayre Bebchuk \& Jesse M. Fried, The Uneasy Case for the Priority of Secured Claims in Bankruptcy, 105 The Yale Law Journal, 857-934, Ch. III, On the Other Efficiency Costs of Full Priority (1996).

48 For further analysis on the power of lenders to replace borrower's managers, see DougLAS G. BAIRD \& Robert K. Rasmussen, Private Debt and The Missing Lever of Corporate Governance, 154 University of Pennsylvania Law Review, 1209-1251, 1209-1211 (2006). Available at: http://scholarship. law.upenn.edu/cgi/viewcontent.cgi?article $=1310 \&$ context $=$ penn_law_review 


\section{B. Minority Shareholder Protection in United Kingdom's Company Law}

In Section I.B of this study, we mentioned that CS could act according to their own interests and thereby expropriate MS from their corporate benefits. We also mentioned that to achieve this purpose, CS might a commit 'tunneling'. ${ }^{49}$ This practice includes, amongst others, the common practices of 'asset sales and contracts such as transfer pricing advantageous to the controlling shareholder, excessive executive compensation, loan guarantees, expropriation of corporate opportunities, and so on' ${ }^{50}$ However, there is another category of tunnelling in which assets are not necessarily diverted from the company, which will be further explained.

One of the main benefits of equity market investors is liquidity, ${ }^{51}$ therefore any shareholder of a given listed company who does not agree with the corporate policy or the management can 'exit' the company by selling his shares at the current price that the market is offering. ${ }^{52}$ On the other hand, the shareholders of private (or non-listed) companies cannot rely on a liquid market to sell their shares when they are in that same situation. Hence, one cause of MS oppression is the inability of MS to exit the company. Indeed, a potential buyer will not acquire the MS participation if he realises that a CS behaves abusively towards the minority and as a result, that he will not get any return from his investment. This situation permits the CS to deprive the MS from corporate benefits until they surrender their shares to the CS at a discounted price. ${ }^{53} \mathrm{Con}$ sequently, when MS are cornered within a company in which they cannot exit, they have to use their political rights to fix the situation,

49 For a deeper study of tunneling, see Simon Johnson, Rafael La Porta, Florencio López-de-Silanes \& Andrei ShleIfer, Tunneling, 90 American Economic Review, 2, 22-27 (2000). Available at: https:// scholar.harvard.edu/shleifer/publications/tunneling

50 Simon Johnson, Rafael La Porta, Florencio López-de-Silanes \& Andrei Shleifer, Tunneling, 90 American Economic Review, 2, 22-27, 23 (2000).

51 Eilís Ferran \& Look Chan Ho, Principles of Corporate Finance Law ( $2^{\text {nd }}$ ed., Oxford University Press, Oxford, 2014).

52 For further investigation on the market-pricing mechanism, see EugEne F. FAma, Efficient Capital Markets: Reply, 31 The Journal of Finance, 1, 143-145 (1976).

53 Benjamin Means, A Voice-Based Framework for Evaluating Claims of Minority Shareholder Oppression in the Close Corporation, 97 The Georgetown Law Journal, 1207-1256 (2009). Available at: http://scholarcommons.sc.edu/cgi/viewcontent.cgi?article=1911\&context=law_facpub 
or in other terms use their 'voice'. ${ }^{54}$ Nonetheless, the latter option tends to be pointless if the MS does not have a blocking minority, as the CS have enough political power to override any propositions offered by the MS and thus keep their expropriation.

The challenge of regulators and courts regarding this matter is to find an adequate balance between the exercise of the exit and voice rights of the MS, and the proprietary rights of $\mathrm{CS}^{55}$ In order to do so, regulators created ex ante mechanisms to prevent tunnelling and ensure the exercise of voice and exit rights. However, taking into account that CS are usually directors or have enough power to secure friendly directors who will act in accordance with their will, the first line of defence against CS abuses is directors' duties. Thus, according to a 'strict' view of these duties, in principle, a director who acts against the interest of the company or in a situation of conflict of interest without the previous informed consent of members will be in breach of his duties, ${ }^{56}$ unless the conduct is ratified by the shareholders meeting. Thus, CS acting as directors, or a friendly director could manifestly act in breach of their duties expecting the ratification of their actions by the general meeting. Consequently, at this point the second line of defence against abuses becomes relevant, which is the requirement that to ratify a 'conduct by a director amounting to negligence, default, breach of duty or breach of trust in relation to the company, ${ }^{57}$ the shareholders meeting has to make a resolution in that fashion, approved by disinterested shareholders. Hence, in a typical case of self-dealing, the acts of the director(s) who made the sale, in breach of their director's duties, cannot be, in principle, ratified by CS. As the beneficiaries of the sale at a discount price are the CS, they become ineligible to ratify the actions of the director(s).$^{58}$ Hence, this uninterested ratification coupled with the directors' duties, provides an apparent effective solution to the

54 Albert Otto Hirschman, Exit, Voice, and Loyalty: Responses to Decline in Firms, Organizations, and States (Harvard University Press, Cambridge, 1970).

55 For further analysis on the approach to minority shareholder protection, see in general BENJAMIN Means, A Voice-Based Framework for Evaluating Claims of Minority Shareholder Oppression in the Close Corporation, 97 The Georgetown Law Journal, 1207-1256 (2009).

56 Ernest Lim, Directors' Fiduciary Duties: A New Analytical Framework, 129 Law Quarterly Review, 2, 242-263 (2013). Available at: https://papers.ssrn.com/sol3/papers.cfm?abstract_id=2368147

57 United Kingdom, Companies Act 2006. Available at: http://www.legislation.gov.uk/ukpga/2006/46/ pdfs/ukpga_20060046_en.pdf

58 United Kingdom, Companies Act 2006, Section 239. 
tunnelling problem. However, the statute does not encompass events in which the directors are instructed by the shareholders meeting (instruction rights) or where the conduct is authorised before it is executed, leaving to courts the duty of deciding on a case by case basis if the conduct amounts to an expropriation of MS. ${ }^{59}$

Consequently, it is impossible to determine ex ante all the reproachable behaviours of the CS and to limit their rights, as its exercise in a certain fashion will always unfairly harm the minority. ${ }^{60}$ Thus, the legislator has created ex post mechanisms; mainly derivative $^{61}$ and unfair prejudice ${ }^{62}$ claims to review the actions of CS. Within this ambit of protection it is possible to find remedies for other types of tunnelling such as the corporate opportunities doctrine, in which the directors are forbidden to exploit business opportunities if their interests may conflict with the interests of the company. ${ }^{63}$ Another type of tunnelling that can be reviewed by courts at the enforcement stage is the excessive remuneration of directors. ${ }^{64}$ By appointing himself, his family or friends as directors and paying them huge salaries, the CS can divest resources from the MS. Thus, as this matter is not addressed by statute, ${ }^{65}$ the courts could assess if the payment of such salaries causes an unfair prejudice to MS. ${ }^{66}$ Finally, another remedy that is worth mentioning is the power invested in the courts to order 'the purchase of the shares of any members of the company by other members or by the company itself ${ }^{367}$ which grants in certain cases an exit right to the MS.

As a consequence of the fashion in which these protections are framed, and as most of the shareholders in non-listed companies do not enter shareholders agreement that provide for self helped

59 David Kershaw, Company Law in Context: Text and Materials, 651 (2 ${ }^{\text {nd }}$ ed., Oxford University Press, Oxford, 2012)

60 Paul L. Davies, Gower and Davies': The Principles of Modern Company Law, 688 (8 ${ }^{\text {th }}$ ed., Sweet \& Maxwell, London, 2008).

61 United Kingdom, Companies Act 2006, Part 11.

62 United Kingdom, Companies Act 2006, Part 30.

63 David Kershaw, Lost in Translation: Corporate Opportunities in Comparative Perspective, 25 Oxford Journal of Legal Studies, 4, 603-627 (2005).

64 Robert Goddard, Excessive Remuneration and the Unfair Prejudice Remedy, 13 Edinburgh Law Review, 3, 517-519 (2009).

65 Section 439 of the Companies Act 2006 applies for quoted companies, which are outside the scope of this research.

66 Scotland, Court of Session, Outer House, Fowler v. Gruber [2009] CSOH 36. Available at: http:// www.bailii.org/scot/cases/ScotCS/2009/2009CSOH36.html

67 United Kingdom, Companies Act 2006, Section 996 (2)(e). 
remedies, ${ }^{68} \mathrm{MS}$ tend to rely on ex post revision of the CS and/or directors' actions by the cumbersome derivative or unfair prejudice claims. ${ }^{69}$ This review requires the court's assessment of the 'unfairness' of the actions, thus, despite Lord Leonard Hubert Hoffmann's willingness 'that lawyers should be able to advise their clients whether or not a petition is likely to succeed' ${ }^{70}$ the court's review depends on a subjective analysis of what seems equitable ${ }^{71}$ and not on an objective financial covenant as in a LA. ${ }^{72}$ Finally, besides the uncertainty that surrounds the enforcement process it is also worth noting that, though some procedural rules might alleviate the burden, ${ }^{73}$ the onus of proving at least a prima facie case ${ }^{74}$ before courts must be borne by MS despite their limited access to corporate documents if they are not directors.

Thus far, it appears that most of the remedies provided by UK law to overcome the CS agency problem are not precisely framed for this purpose. ${ }^{75}$ Moreover, these remedies seem better suited to impede abuses from the managers and not precisely to prevent CS from expropriating MS. Therefore, as will be analysed in the next section, the MS are better protected when a lender is supervising the company than by UK company law.

68 David Kershaw, Company Law in Context: Text and Materials, 650 (2 ${ }^{\text {nd }}$ ed., Oxford University Press, Oxford, 2012).

69 For a detailed analysis of the derivative claim, see: ARAD REISBERg, Derivative Claims under the Companies Act 2006: Much Ado about Nothing?, in Rationality in Company Law: Essays in Honour of DD Prentice, 17-56 (John Armour \& Jennifer Payne, eds., Hart Publishing, London, 2009).

70 United Kingdom, House of Lords, O’Neill v. Phillips [1999] UKHL 24. Available at: https://www. publications.parliament.uk/pa/ld199899/ldjudgmt/jd990520/neill01.htm

71 United Kingdom, House of Lords, O'Neill v. Phillips [1999] UKHL 24.

72 Though the case for derivative actions is different, the court has a considerable amount of discretion to grant permission to continue with the claim and/or to actually decide in favour of the claimant.

73 In particular those modified by the Companies Act 2006 and the Civil Procedure Rules. United Kingdom, Companies Act 2006. United Kingdom, Civil Procedure Rules, Rule 31. Available at: https://www.justice.gov.uk/courts/procedure-rules/civil/rules/part31

74 United Kingdom, Companies Act 2006, Section 261(2).

75 Brian R. Cheffins makes this point relating to listed companies. However, we believe that the analysis is valid for non-listed companies, just as UK company law, in particular the Companies Act 2006, is applicable to both types of companies. BRIAn R. Cheffins, The Undermining of UK Corporate Governance (?), 6 (University of Cambridge, Faculty of Law, Research Paper 4/2013 (2013). Available at: http://ssrn.com/abstract=2129686, https://papers.ssrn.com/sol3/papers.cfm?abstract_id=212968 $6 \&$ rec $=1 \&$ srcabs $=1953190 \&$ alg $=1 \&$ pos $=5$ 


\section{LOAN AGREEMENT EXTERNALITIES}

In Section II we discussed the way in which lenders protect themselves from the borrower as well as how UK company law protects MS from the CS abuses. However, the focus of this research, and its contribution is to make a theoretical approach on how the externalities produced by LA can help to overcome the CS agency problem and if MS are better protected by LA than by UK company law. Thus, this section will study how LA protect MS and how the incentives they create tend to align the interests of directors, MS and CS. Thereafter we will assess the effectiveness of the protection given by LA to MS as compared to UK company law, in order to demonstrate which mechanism is best placed to protect MS interests.

\section{A. Protection and Incentives Created by the Loan Agreement}

Firstly, it is important to establish how LA change the incentives of some constituencies within a company, and therefore align the interests of the shareholders to an extent in which the CS agency problem tends to disappear. As we mentioned in Section II.B, CS may exercise their corporate power to deprive MS from corporate benefits and earn private benefits of control. In order to achieve this purpose, CS 'tunnel' the company's assets before they reach the MS as dividends. ${ }^{76}$ However, the covenants as well as the dynamics of the relationship between borrower and lender act as a deterrent for CS from engaging in tunnelling activities. Thus, LA create incentives for directors and shareholders to efficiently run the company and make proper use of its assets, aligning the interests of these constituencies and helping to reduce the CS agency problem.

One option that CS have to divest company's assets is to authorise directors to transfer some corporate assets at a discounted price to another company in which CS have bigger holdings. ${ }^{77}$ However,

76 See in general Simon Johnson, Rafael La Porta, Florencio López-De-Silanes \& Andrei Shleifer, Tunneling, 90 American Economic Review, 2, 22-27 (2000).

77 It is worth noticing that as we mentioned in Section II.B, authorisation of the shareholders meeting is outside the scope of section 239 of the Companies Act and therefore it is for the courts to decide on its fairness. David Kershaw, Company Law in Context: Text and Materials, 651 ( $2^{\text {nd }}$ ed., Oxford 
a common covenant is the requirement of lenders' approval when borrowers are disposing of their assets outside the ordinary course of trading. Hence, it is unlikely that lenders will allow assets disposals at a reduced price, as it will diminish the company's value and creditworthiness. Alternatively, assuming that a borrower manages to obtain the lender's approval, another common protection of LA are the 'sweep' covenants, which require the borrower to pay a certain amount of their loan to the lender after a company's asset sale. ${ }^{78}$ Consequently, these provisions will either impede CS from effecting the sale, or from accumulating free cash flow to divest. Thus, though these provisions are designed to prevent borrowers from incurring asset dilution, one of its externalities is that it impedes CS from entering into tunnelling activities.

Similarly, CS can tunnel resources by excessively remunerating their company's executives and/or by exploiting, by themselves or through friendly directors, commercial opportunities that 'belong' to the company. The second scenario is what has been known as the corporate opportunities doctrine, which focuses on when 'a director should be allowed to personally exploit a business opportunity which was encountered during his tenure' ${ }^{79}$ The corporate opportunities doctrine approach in the UK has been protective of the company's property, and therefore reluctant to allow directors to exploit opportunities that could fall within the scope of the company's business. ${ }^{80}$ Accordingly, the 'director of a company must avoid a situation in which he has, or can have, a direct or indirect interest that conflicts, or possibly may conflict, with the interests of the company. ${ }^{91}$ However, it is important to notice that this is not an absolute rule, and therefore if the shareholders, acting in a non-fiduciary capacity, can block the initiative, the opportunity becomes available for the directors to exploit. ${ }^{82}$ Thus, CS, in principle, could exercise their

University Press, Oxford, 2012).

78 Joanna M. Shepherd, Frederick Tung \& Albert H. Yoon, What Else Matters for Corporate Governance?: The Case of Bank Monitoring, 88 Boston University Law Review, 4, 991-1041, 1010 (2008).

79 David Kershaw, Lost in Translation: Corporate Opportunities in Comparative Perspective, 25 Oxford Journal of Legal Studies, 4, 603-627 (2005).

80 See United Kingdom, House of Lords, Aberdeen Railway Co. v. Blaikie (1854) 17 D (HL) 20 and England and Wales Court of Appeal, Bhullarv. Bhullar [2003] BCC 711 (Court of Appeal). Available at: http://www.bailii.org/ew/cases/EWCA/Civ/2003/424.html

81 United Kingdom, Companies Act 2006, Section 175.

82 See England and Wales High Court of Justice, Wilkinson v. West Coast Capital [2005] EWHC 3009 (Chancery Division), paras. 297-310. 
voting power to frustrate a given commercial opportunity for the company, and exploit it by themselves or allow friendly directors to do so. ${ }^{83}$

Excessive remuneration and corporate opportunities misbehaviours seem out of the reach of LA covenants. Moreover, during the years prior to the last financial crisis, when the market had an excess of liquidity and money was cheap, the lenders lost their ' $l e$ $v e r^{84}$ to force managerial exits as the market conditions made the lenders compete amongst themselves by relaxing their standards. Therefore, LA became 'covenant-lite' or 'covenant loose', and thus it created systemic risk. ${ }^{85}$ Nevertheless, it has to be borne in mind that both practices can reduce the value and creditworthiness of borrowers. Hence, despite no particular standard covenant fully addressing the value reduction that can be caused by excessive remuneration and the loss of corporate opportunities, lenders still have bargain power to correct and prevent these situations.

A 2009 study in the United States showed that more than $90 \%$ of the long-term debt contracts are renegotiated before their maturity. ${ }^{86}$ This means that, despite less than $20 \%$ of renegotiations being the direct or indirect outcome of covenant violations or payment default, ${ }^{87}$ lenders have the 'certainty of renegotiation' ${ }^{88}$ Hence, if lenders realise that the cash available to repay them is being used to pay exorbitant salaries to the company's directors, they have both the incentives and the tools to request corrective measures. Correspondingly, if a lender becomes aware that borrowers' directors are underperforming by not pursuing profitable projects for their

83 England and Wales High Court of Justice, Wilkinson v. West Coast Capital [2005] EWHC 3009 (Chancery Division), paras. 297-310, but the court mentioned an eventual different outcome under Section 176 of the Companies Act 2006 (duty not to accept benefits from third parties).

84 The term was coined by Baird and Rasmussen. Douglas G. Baird \& Robert K. Rasmussen, Private Debt and The Missing Lever of Corporate Governance, 154 University of Pennsylvania Law Review, 1209-1251, 1211 (2006).

85 Viral V. Acharya, Julian Franks \& Henri Servaes, Private Equity: Boom and Bust?, 19 Journal of Applied Corporate Finance, 4, 44-53 (2007).

86 Michael R. Roberts \& Amir Sufi, Renegotiation of Financial Contracts: Evidence from Private Credit Agreements, 93 Journal of Financial Economics, 159-184 (2009). Available at: http://finance. wharton.upenn.edu/ mrrobert/resources/Publications/RenegotiationJFE2009.pdf

87 Michael R. Roberts \& Amir Sufi, Renegotiation of Financial Contracts: Evidence from Private Credit Agreements, 93 Journal of Financial Economics, 159-184, 160 (2009).

88 Frederick Tung, Leverage in the Board Room: The Unsung Influence of Private Lenders in Corporate Governance, 57 UCLA Law Review, 115-181, 141 (2009). 
companies, or worse, by 'stealing' those projects from the company, they might force the exit of the company's management. ${ }^{89}$

Alternatively, an underperforming company usually has to pay higher interest rates for its loans if an 'interest-increasing performance pricing ${ }^{90}$ provision has been agreed. Thus, CS not only have few incentives to let others (or themselves in a different capacity) exploit the corporate opportunities (as the lender can demand the exit of the underperforming or disloyal directors); they also have a deterrent to do so. If their shareholding in the company is substantial, a rise in the interest rate of its credit can wipe out the extra profit achieved when exploiting by themselves or through others, the commercial opportunity making it pointless to engage in such activities.

On the other hand, as we considered before, the efficacy of LA is usually enhanced by adding to covenants and events of default drafting security interests in the form of floating charges. ${ }^{91}$ In particular, we mentioned that if the charge becomes enforceable by the occurrence of a crystallising event (often an event of default), secured creditors (lenders) are entitled to appoint an administrator without resorting to court..$^{92}$ As a result, though directors will remain in office after the appointment, they will by 'sidelined' ${ }^{\prime 3}$ by the administrator, and they will therefore lose their influence in the company's affairs and even their own jobs if the administration process finalises with the sale of the company or its business to a third party ${ }^{94}$ Hence, despite the fact that directors might owe allegiance to CS, it is unlikely that they will be willing to jeopardise

89 For further details about the forced exit of Scott Livengood, Krispy Kreme's CEO, in May 2004, by request of its lenders, see Douglas G. Baird \& Robert K. Rasmussen, Private Debt and The Missing Lever of Corporate Governance, 154 University of Pennsylvania Law Review, 1209-1251, 1209-1211 (2006).

90 For an enhanced analysis on this topic, see Paul Asquith, Anne Beatty \& Joseph Weber, Performance Pricing in Bank Debt Contracts, 40 Journal of Accounting and Economics, 101-128 (2005). Available at: https://www.academia.edu/18287465/Performance_pricing_in_bank_debt_contracts

91 See Section II.A.

92 Despite the autonomy of the lender to appoint an administrator, it is necessary to file the documents requested on Sch. B1 para. 18 of the Insolvency Act 1986 to court for the appointment to commence. United Kingdom, Insolvency Act 1986.

93 Jennifer Payne, Debt Restructuring in English Law: Lessons from the US and the Need for Reform, 15 (Oxford Legal Research Paper Series 89/2013, 13, 2014).

94 Jennifer PAYne, Debt Restructuring in English Law: Lessons from the US and the Need for Reform, 15 (Oxford Legal Research Paper Series 89/2013, 13, 2014). Jennifer Payne explains that the failure of a company is commonly associated with a failure in management. 
their jobs and reputation by engaging into tunnelling activities that might trigger a crystallising event. This in turn might result in the appointment of an administrator who will expose their wrong doings and thus harm their future opportunities in other companies.

Furthermore, CS have an additional important deterrent to engage in these types of activities, as secured creditors (lenders) can sell the company or its assets overnight and leave them stranded. Through a 'pre-packed administration' process, the sale of the company or its assets can be agreed by secured creditors and potential buyers before the appointment of the administrator, and is effected by the administrator soon after the appointment commences, leaving shareholders empty handed without any warning..$^{95}$ Therefore, despite the security interest tending to be a tool for lenders to reduce their credit risk in insolvency scenarios, the threat of administration is an effective deterrent for directors and CS to avoid practices that may harm the financial shape of companies or their value, as doing it could make the qualifying floating charge enforceable and thus damage their careers or their property.

Finally, MS are also affected by LA, as they are tools to amplify their voice rights. The protections provided by LA rely almost entirely on the supervision exercised by lenders, as covenant breaches, events of default and crystallising events can pass undetected. ${ }^{96}$ Thus, MS have incentives to be vigilant of the other constituencies in order to alert lenders of any situation that could affect the company's value or its financial situation. Consequently, MS will improve their situation within the company if they proactively scrutinise the actions of the other constituencies, as despite their lack of corporate power their interests overlap with lenders' interests. Hence, both lenders and MS seek to impede other constituencies from extracting value from the company, as successfully doing so would increase the amount of resources to repay the loan or distribute as dividends to them. ${ }^{97}$

95 For a deeper analysis of pre-pack administration, see VANESSA FINCH, Pre-Packaged Administrations and the Construction of Propriety, 11 Journal of Corporate Law Studies, 1, 1-31 (2011).

96 See Louise Gullifer \& Jennifer Payne, Corporate Finance Law: Principles and Policy, 202-206, for an analysis of monitoring as essential to enforce negative pledge covenants.

97 For further analysis on how the lender interacts with the other constituencies, see GEORGES G. TRIANTIS \& Ronald J. Daniels, The Role of Debt in Interactive Corporate Governance, 83 University of California Law Review, 4, 1073-1113 (1995). 
The result of the above mentioned externalities on directors and in particular on CS and MS has the ultimate effect of aligning the interests of these constituencies towards the same end: the success of the company. As we mentioned LA curb CS attempts to cash out money or benefits from the company. Therefore, CS will have to promote the efficient use of the company's assets (including the company's opportunities) to produce enough resources to repay the loan and distribute dividends. Likewise, directors will be careful not to clash with the restrictions included in LA to keep their positions and reputations, and thus will not enter into tunnelling activities. Finally, MS and lenders will supervise the compliance of other constituencies to increase (or at least not allow to decrease) the company's value, with the goal of producing enough income to pay the lender, and dividends to shareholders.

\section{B. UK Company Law v. Loan Agreements}

In Section II it was explained how company law and lenders address the agency problems that might arise between shareholders and between borrowers and lenders. Similarly, in Section III.A we have seen how the measures taken by lenders to reduce their exposure to the borrower agency problem help to mitigate the CS agency problem. However, we must now assess which of the two approaches provides a more efficient and effective protection against the CS agency problem. To address the efficiency question we will compare these protective measures through the scope of the standards $v$. rules debate. ${ }^{98}$ Nevertheless, the emphasis of the analysis lies in the differences that LA have with rules. The dynamics surrounding LA, contrast them with the conventional 'bluntness ${ }^{\prime 99}$ that characterises rules on this debate, which makes this protection more efficient than UK company law protection. Then, to determine which approach is more effective, we will argue that UK company law stretched the existing managerial agency problem framework to include minority protections, and that LA as specifically tailored documents provide

98 This debate was started by Isaac Ehrlich \& Richard A. Posner, An Economic Analysis of Legal Rulemaking, 3 The Journal of Legal Studies, 1, 257-286 (1974).

99 Ezra Friedman \& Abraham L. Wickelgren, A New Angle on Rules versus Standards, 16 American Law and Economics Review, 2, 499-549 (2014). 
a more effective protection than the ex post 'standard' revisions prescribed by UK company law. However, MS could use UK company law as a last resort when lenders do not react to CS abuses.

The protection that UK company law provides against MS abuse is divided into two parts. Firstly, it establishes a procedural rule, which impedes 'connected' members to ratify breaches of director's duties. However, as we already explained, this provision can be, at least on a prima facie basis, circumvented using previous authorisations or instruction rights. This leads us to the second stage of protection, court intervention. In the second stage, courts have to determine if CS behaviour created an unfair prejudice for MS, or if the actions of the directors involve 'negligence, default, breach of duty or breach of trust' ${ }^{100}$ On the other hand, LA are comprehensive documents that have detailed descriptions of the obligations and rights of each party ${ }^{101}$ and more importantly, it provides for self-helped remedies that entitle the complying party to act without resorting to court. Therefore, it could be argued that UK company law tends to establish a 'standards' approach, whereas LA privilege a 'rules'102 approach.

The basis of this debate is, on one side, that standards are flexible but costly to enforce, as they rely on a full revision of the merits. Therefore, one could say that the latter two characteristics can be found in UK company law protection. Unfairness and negligence are wide reach standards that could encompass several types of abusive behaviours. Thus, as there is no individual description of the restricted behaviours, these types of norms are cheaper to create than rules. ${ }^{103}$ Moreover, as they are not described in detail they are hard to circumvent and easy to adapt to new forms of abusive behaviours, which make them flexible. However the 'openness' of its form has a downside, the necessity to rely on third parties to determine if the standard has been breached. This ex post revision

100 Companies Act 2006, Section 260(3).

101 Douglas G. Baird \& Robert K. Rasmussen, Private Debt and The Missing Lever of Corporate Governance, 154 University of Pennsylvania Law Review, 1209-1251, 1217 (2006).

102 Isaac Ehrlich \& Richard A. Posner, An Economic Analysis of Legal Rulemaking, 3 The Journal of Legal Studies, 1, 257-286, 258 (1974). Though the authors expressly excluded from their analysis 'private rules' as loan agreements, we believe that some aspects of the debate can be applied to these types of 'rules' in order to compare their effectiveness.

103 Louis Kaplow, Rules versus Standards: An Economic Analysis, 42 Duke Law Journal, 3, 557-629 (1992). Available at: http://scholarship.law.duke.edu/cgi/viewcontent.cgi?article=3207\&context=dlj 
of the conduct makes standards costly to enforce for all the parties involved. ${ }^{104}$ We have then a situation where UK company law provides a flexible and costly ex post revision of standards that encompasses a wide range of actions taken by CS and/or directors that could harm MS interests. Thus, the most appealing feature of UK company law is its flexibility, an alleged drawback from rules.

On the other hand, rules are seen as cheap to enforce and predictable, but costly to create ${ }^{105}$ and unable 'to adjust the decision to case-specific circumstances'. ${ }^{106}$ Conversely to standards, rules describe in detail a conduct, and thus the debate about its breach is fact specific, ${ }^{107}$ which makes them cheap to enforce and easy to predict. Nevertheless, as conducts have to be describe ex ante, creating the rule involves incurring in costs to prevent the 'overinclusion or underinclusion ${ }^{108}$ of conducts within the rule and make it ideal to safeguard the relevant interests. Likewise, the specificity of the conducts described in a rule reduces its scope putting all the non-included conducts out of its reach, making them easier to circumvent and less flexible to adapt to new misbehaviours than standards. However, though LA have the two qualities of rules, the dynamics of the loan industry made them cheap to create and flexible.

Most LA are renegotiated before their maturity, which is particularly important for our analysis in two aspects. Firstly, renegotiation gives LA flexibility; in fact lenders see LA 'as a living document destined to be modified periodically to take account of changing circumstances'. ${ }^{109}$ Secondly, the fact that LA are to be renegotiated diminishes the costs of its creation, as harmful behaviours of CS that were not foreseen when the LA was entered can be included afterwards, thus LA can be framed according to the information

104 For a comprehensive analysis of the costs attached to standards and rules systems, see IsAAC EHRLICH \& Richard A. Posner, An Economic Analysis of Legal Rulemaking, 3 The Journal of Legal Studies, 1, 257-286 (1974).

105 Louis Kaplow, Rules versus Standards: An Economic Analysis, 42 Duke Law Journal, 3, 557-629, 562 (1992). Available at: http://scholarship.law.duke.edu/cgi/viewcontent.cgi?article=3207\&context=dlj

106 Ezra Friedman \& Abraham L. Wickelgren, A New Angle on Rules versus Standards, 16 American Law and Economics Review, 2, 499-549, 499 (2014).

107 Lous Kaplow, Rules versus Standards: An Economic Analysis, 42 Duke Law Journal, 3, 557-629, 560 (1992). Available at: http://scholarship.law.duke.edu/cgi/viewcontent.cgi?article=3207\&context=dlj

108 Isaac Ehrlich \& Richard A. Posner, An Economic Analysis of Legal Rulemaking, 3 The Journal of Legal Studies, 1, 257-286, 267 (1974).

109 Edward D. Zinbarg, The Private Placement Loan Agreement, 31 Financial Analysts Journal, 4, 33-35 (1975). 
that lenders can cheaply acquire from a borrower ${ }^{110}$ reducing the costs of its creation. Furthermore, lenders can rely on guidelines and standard documents created by trading associations that incorporate market best practices, reducing the costs of creating LA. ${ }^{111}$ Hence, one could say that LA as measures to address the CS agency problem are cheap to create and enforce, and at the same time flexible. Thus LA have the positive attributes of both rules and standards, and therefore, provide a more efficient protection to MS.

For the effectiveness analysis, is important to point out that LA are detailed documents with a precise description of the obligations and rights of each party. Furthermore, LA are framed according to borrowers' reputation and the information that lenders have from them. ${ }^{112}$ Nevertheless, the main feature of LA is the 'lever' that the 'certainty of renegotiation' gives to lenders in order to exercise de facto rights against borrowers' misbehaviours. The threat of calling the loan gives lenders a sizeable bargain power that makes LA efficient tools to protect the value of the company and to impede the divestment of its resources.

A different scenario can be found in UK company law, in which, as mentioned before, the focus is to deter the managerial agency problem. This approach is consistent with the UK shareholders structure of listed companies. ${ }^{113}$ Thus the corporate governance regime in the UK was thought up for widely held companies without $\mathrm{CS}^{114}$ and therefore its regulation targets 'arm's-length investors'. As a consequence, the arrival of foreign companies with $\mathrm{CS}$ into the London Stock Exchange was followed by various corporate scandals of CS opportunistic behaviours. ${ }^{115}$ However, the regulatory

110 Charles K. Whitehead, The Evolution of Debt: Covenants, the Credit Market, and Corporate Governance, 34 The Journal of Corporation Law, 3, 101-137 (2009). Available at: https://papers. ssrn.com/sol3/papers.cfm?abstract_id=1205222

111 On this particular topic the Loan Market Association stands out.

112 Charles K. Whitehead, The Evolution of Debt: Covenants, the Credit Market, and Corporate Governance, 34 The Journal of Corporation Law, 3, 101-137, 112 (2009).

113 Rafael La Porta, Florencio LóPez-de-Silanes \& Andrei Shleifer, Corporate Ownership around the World, 54 The Journal of Finance, 2, 471-517, Table II (1999).

114 Brian R. ChefFins, The Undermining of UK Corporate Governance (?) (University of Cambridge, Faculty of Law, Research Paper 4/2013 (2013). Iris H-Y Chiu \& Roger M. BARker, Protecting Minority Shareholders in Blockholder-Controlled Companies - Evaluating the UK's Enhanced Listing Regime in Comparison with Investor Protection Regimes in New York and Hong Kong, 10 Capital Markets Law Journal, 1, 98-132 (2014). Available at: https://papers.ssrn.com/sol3/papers. cfm?abstract id=2469759

115 i.e. Bumi and Eurasian Natural Resources Corporation, ENRC. 
response came from securities regulation and not from company law, ${ }^{116}$ despite the fact that most UK companies are private and not widely held. In fact, UK protections of shareholders from other shareholders have scarcely increased since $1970 .{ }^{117}$

Apart from the already discussed limitations from the regulation on the ratification of breaches of director's duties, other provisions have shortcomings when they are applied to protect MS. Two examples of these limitations are the regulation of substantial property transactions ${ }^{118}$ and the duty to declare interest in proposed transactions or arrangements. ${ }^{119}$ The rationale behind these two provisions is to protect the assets of a company by preventing its asset stripping. However, they only include within their scope the directors of the company, leaving CS, who have an important discretion to remove the directors if they are not allied with their interests, ${ }^{120}$ out of their reach. ${ }^{121}$ Consequently, 'regulation under UK company law... does not provide all of the answers for 'tunnelling. ${ }^{122}$ Therefore, as UK company law provisions are framed to deter directors from acting against shareholders interests, when they are stretched to address the CS agency problem, they do not properly do so, as they rely excessively on the role of courts to enforce wide standards. However, litigation costs are considerable, hence MS cannot always afford them, therefore a regulation that relies mainly on courts is not as effective as a regime in which lenders have means to enforce their rights and thus act as MS champions.

Consequently, the bargaining power that LA provide to lenders make them prevent the divestment of company resources and ultimately discourages CS from gaining private benefits of control - but in this case without resorting to court, as opposed to UK company law. This difference makes MS protection under LA more effective than under UK company law, in particular because shareholders

116 BRIAN R. ChEFFIns, The Undermining of UK Corporate Governance (?) (University of Cambridge, Faculty of Law, Research Paper 4/2013 (2013).

117 Priya P. Lele \& Mathias M. Siems, Shareholder Protection: A Leximetric Approach, 7 Journal of Corporate Law Studies, 1, 17-50 (2007).

118 Companies Act 2006, Sections 190-196.

119 Companies Act 2006, Section 177.

120 Companies Act 2006, Section 168.

121 BRIAN R. CHEFFInS, The Undermining of UK Corporate Governance (?), 36-38 (University of Cambridge, Faculty of Law, Research Paper 4/2013 (2013).

122 BRIAn R. ChefFIns, The Undermining of UK Corporate Governance (?), 38 (University of Cambridge, Faculty of Law, Research Paper 4/2013 (2013). 
can benefit without paying for lenders' supervision. However, despite not reaching the same efficiency and effectiveness levels of LA protection, UK company law plays a pivotal role in MS protection in particular, when lenders' supervision fails.

\section{DRAWBACKS OF LENDERS SUPERVISION}

In this final section we will study the possible drawbacks of lenders' supervision for MS. As we mentioned in section IV, lenders' and MS interests overlap as both want to prevent the misuse of corporate assets and to run the company efficiently, so it can generate profits to repay the lenders and distribute dividends to shareholders. Indeed, lenders and MS have incentives to monitor the activities of other constituencies (CS and directors) to prevent them from entering into activities that might harm the value of the company. Nonetheless, lenders' interests can sometimes collide with those of the shareholders as 'there is no easier way for a company to escape the burden of a debt than to pay out all of its assets in the form of a dividend, and leave the creditors holding an empty shell. ${ }^{123}$ Likewise, lenders can hedge their credit risk with credit derivatives engaging in a practice known as 'debt decoupling', ${ }^{124}$ which consists of the 'unbundling of the economic rights, contractual control rights, and legal and other rights normally associated with debt, through credit derivatives and securitization'. ${ }^{125}$ This decoupling changes the incentives that lenders have for supervising borrowers, and worse, their interests in the company's success. However, as we will demonstrate, the conflicts arising in both scenarios are apparent, and thus MS are better protected by the lenders' supervision than by UK company law.

\section{A. Dividend Restriction Covenants}

Despite the common interest in company's success, lenders and MS can antagonise each other on the dividends policy. As we mentioned

123 Fischer Black, The Dividend Puzzle, 2 Journal of Portfolio Management, 2, 5-8 (1976). The author refers to bond-holders but the expression is equally valid for lenders.

124 Henri T. C. Hu \& Bernard Black, Debt, Equity and Hybrid Decoupling: Governance and Systemic Risk Implications, 14 European Financial Management, 4, 663-709 (2008).

125 Henri T. C. Hu \& Bernard Black, Debt, Equity and Hybrid Decoupling: Governance and Systemic Risk Implications, 14 European Financial Management, 4, 663-709 (2008). 
in Section I.A., the source of this dispute is that shareholders can dilute the assets of the company and transfer its value to them through the payment of dividends, increasing the lenders' credit risk. To avoid this situation, lenders include dividend restriction covenants on their LA, which usually consist either of a complete restriction on the payment of dividends, or the payments of dividends only from a previously constituted inventory. ${ }^{126}$ The latter option normally includes in the inventory fund all the resources coming from share issuances, one half of the profits and subtracts the total losses. ${ }^{127}$ This covenant might seem harmful for MS, as they restrict the sole source of income that they might have in the company (assuming that they don't occupy any seat on the board or any relevant job within the company), however this conclusion is not always right, as the interests of MS are affected only in the short term.

In the first scenario, shareholders are not allowed to receive any dividends from the company while the covenant restriction is in place. This measure coupled with the other covenants that we already explained impedes the CS to extract not only private benefits of control, but any benefit at all from the company. As a consequence, $\mathrm{CS}$ will be forced to avoid engaging in tunnelling and other types of actions that increase the lenders' credit risk, aiming to renegotiate the $\mathrm{LA}^{128}$ in a fashion that will enable them to cash out some resources. Nevertheless, it is unlikely that lenders will loosen up covenants that might facilitate misbehaviours from CS or directors. Hence, the borrower has to bargain for the possibility of distributing dividends by removing the restriction altogether, or by loosening it and making the distribution available with the resources of the above-mentioned inventory.

The first case will release dividends and therefore MS will have access to corporate benefits. In the second case, the inventory pool

126 Boochun Jung, Woo-Jong Lee \& Yanhua Sunny Yang, The Impact of Dividend Covenants on Investment and Operating Performance, 43 Journal of Business Finance \& Accounting, 3-4, 414-447 (2016).

127 Boochun Jung, Woo-Jong Lee \& Yanhua Sunny Yang, The Impact of Dividend Covenants on Investment and Operating Performance, 43 Journal of Business Finance \& Accounting, 3-4, 414-447 (2016).

128 About covenants tailored according to the borrower's reputation, see ChARLES K. WhiteHEAD, The Evolution of Debt: Covenants, the Credit Market, and Corporate Governance, 34 The Journal of Corporation Law, 3, 101-137 (2009). 
can be increased by either the issuance of shares or by half of the company's profits. CS will rarely use the former option, as it would be like pulling money out of one pocket to put it in the other, or to dilute their shareholdings. However, the second option will be to make sure that the company is run efficiently and produces enough profits to distribute half of them as dividends. Therefore, again the interests of all our constituencies are aligned and thus MS interests will only be put aside in the short term with no irreparable harm.

\section{B. Debt Decoupling}

The other scenario in which lender supervision can be adverse for MS is when lenders hedge their position on the LA, or speculate against it with credit default swaps (CDS). These agreements are entered into by lenders (protection buyers), who pay a fee or a premium to a protection seller, who will pay a pre fixed amount to the lenders if a 'credit event' occurs. ${ }^{129}$ Once entered, the CDS lenders transfer the risk of borrower's default to a protection buyer and therefore have no incentives to supervise the borrower's activity, as they will be repaid either by the borrower or by the protection seller. Moreover, the lender can be over-hedged and actually make a better return if the borrower defaulted than if the borrower repaid him..$^{130}$ Hence, some scholars argue that the assumption 'that creditors are normally interested in keeping a solvent firm out of bankruptcy... can no longer be relied on'. ${ }^{131}$

Conversely, other recent literature suggests that despite the decoupling, lenders still have incentives to supervise the borrowers behaviour. ${ }^{132}$ According to this literature, the market for CDS is interconnected (a protection seller can afterwards buy protection from its protection buyer) and specialised (banks tend to be net

129 For further analysis of complications to call the credit event in the Greek default, see ANNA GELPERN \& Mitu Gulati, CDS Zombies, 13 European Business Organization Law Review, 347-390 (2012). Available at: http://scholarship.law.duke.edu/cgi/viewcontent.cgi?article $=5336 \&$ context $=$ facul ty_scholarship

130 FREDERICK Tung, Leverage in the Board Room: The Unsung Influence of Private Lenders in Corporate Governance, 57 UCLA Law Review, 115-181, 167-169 (2009).

131 Henri T. C. Hu \& Bernard Black, Debt, Equity and Hybrid Decoupling: Governance and Systemic Risk Implications, 14 European Financial Management, 4, 663-709 (2008).

132 Yesha Yadav, The Case for a Market in Debt Governance, 67 Vanderbilt Law Review, 3, 771-835 (2014). 
protection buyers whereas pension funds tend to be net protection sellers) which makes it prone to cooperation between its participants. ${ }^{133}$ Therefore, it is suggested that letting a borrower fail as a consequence of the lender's lack of supervision can harm the lender's reputation on the CDS market. ${ }^{134}$ Likewise bullying the borrower by denying waivers for the breach of technical (not essential) covenants to create a credit event can also make the lender lose potential clients on the loan market, as they will prefer a more flexible lender. It is also worth mentioning that protection sellers do have incentives to keep the creditworthiness of borrowers, and lenders have incentives to appear as such in front of the borrower, ${ }^{135}$ hence lenders and protection buyers have incentives to share the monitoring costs and keep close attention to the borrower's creditworthiness. ${ }^{136}$ Furthermore a lender that fails to exercise its monitoring power over the borrower, or acts recklessly about it, may face higher premiums to buy CDS or an overall ban of the CDS market (as it is interconnected). ${ }^{137}$ Therefore, despite having shifted the risk away from its books, lenders still have incentives to monitor the borrower's behaviour and thus to protect MS interests by keeping the value and financial shape of the company.

133 Yesha Yadav, The Case for a Market in Debt Governance, 67 Vanderbilt Law Review, 3, 771-835 (2014).

134 Yesha Yadav, The Case for a Market in Debt Governance, 67 Vanderbilt Law Review, 3, 771-835, 806 (2014).

135 Borrowers would not be happy to realise that the lender is sharing its financial information with a protection seller.

136 Yesha Yadav, The Case for a Market in Debt Governance, 67 Vanderbilt Law Review, 3, 771-835, 810 (2014).

137 Yesha Yadav, The Case for a Market in Debt Governance, 67 Vanderbilt Law Review, 3, 771-835, 812-814 (2014). 


\section{CONCLUSION}

In short, MS are better protected by the externalities arising from LA entered by the company than by UK company law. As has been demonstrated, the relationships between lenders and borrowers as well as between MS and CS give rise to agency problems, which are addressed in different ways. Whereas lenders are seen as adjusting creditors, and thus able to protect by themselves through contractual drafting and security interests that can be self enforced, MS are protected by broad standards that require the intervention of courts for their enforcement. However, the analysis of LA shows that the protections granted by LA is such that CS have no other option than to avoid misbehaviours that could trigger events of default, and thus LA align the interests of CS and MS reducing the CS agency problem. Moreover LA have the positive attributes of rules and standards, and therefore, provide a more efficient protection to MS than UK company law which is designed to protect shareholders from managers, and thus when stretched to protect MS from CS, over relies on courts for enforcement. Finally, despite the criticisms regarding the use of dividend covenants and CDS, lenders still have incentives to supervise borrowers and their interests overlap with those from the MS making them their champions. 


\section{BIBLIOGRAPHY}

\section{Books}

Buxton, Tony; Chapman, Paul \& Temple, Paul, Britain's Economic Performance (Routledge, London, 2005).

Davies, Paul L., Gower and Davies': The Principles of Modern Company Law (8th ed., Sweet \& Maxwell, London, 2008).

Ferran, Eilís \& Ho, Look Chan, Principles of Corporate Finance Law ( $2^{\text {nd }}$ ed., Oxford University Press, Oxford, 2014).

Gullifer, Louise \& Payne, Jennifer, Corporate Finance Law: Principles and Policy ( $2^{\text {nd }}$ ed., Hart Publishing, Oxford, 2015).

Kershaw, David, Company Law in Context: Text and Materials ( $2^{\text {nd }}$ ed., Oxford University Press, Oxford, 2012).

Kraakman, Reinier; Armour, John; Davies, Paul; Enriques, Luca; Hansmann, Henry; Hertig, Gerard; Hopt, Klaus; Kanda, Hideki; Pargendler, Mariana; Ringe, Wolf-Georg \& Rock, Edward, The Anatomy of Corporate Law. A Comparative and Functional Approach ( $2^{\text {nd }}$ ed., Oxford University Press, Oxford, 2009).

\section{Contribution in collective books}

Armour, John; Hansmann, Henry \& Kraakman, Reinier, Agency Problems and Legal Strategies, in The Anatomy of Corporate Law. A Comparative and Functional Approach, 29-48 ( $2^{\text {nd }}$ ed., Reinier Kraakman, John Armour, Paul Davies, Luca Enriques, Henry Hansmann, Gerard Hertig, Klaus Hopt, Hideki Kanda, Mariana Pargendler, Wolf-Georg Ringe \& Edward Rock, Oxford University Press, Oxford, 2009).

Reisberg, Arad, Derivative Claims under the Companies Act 2006: Much Ado about Nothing?, in Rationality in Company Law: Essays in Honour of DD Prentice, 17-56 (John Armour \& Jennifer Payne, eds., Hart Publishing, London, 2009).

\section{Journals}

Acharya, Viral V.; Franks, Julian \& Servaes, Henri, Private Equity: Boom and Bust?, 19 Journal of Applied Corporate Finance, 4, 44-53 (2007).

Asquith, Paul; Beatty, Anne \& Weber, Joseph, Performance Pricing in Bank Debt Contracts, 40 Journal of Accounting and Economics, 101-128 (2005). Available at: https://www.academia.edu/18287465/Performance_pricing_in_bank_debt_ contracts

Baird, Douglas G. \& Rasmussen, Robert K., Private Debt and The Missing Lever of Corporate Governance, 154 University of Pennsylvania Law Review, 12091251 (2006). Available at: http://scholarship.law.upenn.edu/cgi/viewcontent. cgi?article $=1310 \&$ context $=$ penn_law_review 
Bebchuk, Lucian Ayre \& Fried, Jesse M., The Uneasy Case for the Priority of Secured Claims in Bankruptcy, 105 The Yale Law Journal, 857-934 (1996). Available at: http://www.law.harvard.edu/faculty/bebchuk/pdfs/tylj.96.bebchuk-fried.pdf, https://papers.ssrn.com/sol3/papers.cfm?abstract_id=417960

Black, Fischer, The Dividend Puzzle, 2 Journal of Portfolio Management, 2, 5-8 (1976).

Chiu, Iris H-Y \& BArker, Roger M., Protecting Minority Shareholders in BlockholderControlled Companies - Evaluating the UK's Enhanced Listing Regime in Comparison with Investor Protection Regimes in New York and Hong Kong, 10 Capital Markets Law Journal, 1, 98-132 (2014). Available at: https://papers.ssrn. com/sol3/papers.cfm?abstract_id=2469759

Coffee, John C., A Theory of Corporate Scandals: Why the USA and Europe Differ, 21 Oxford Review of Economic Policy, 2, 198-211 (2005)

Ehrlich, Isaac \& Posner, Richard A., An Economic Analysis of Legal Rulemaking, 3 The Journal of Legal Studies, 1, 257-286 (1974).

Enriques, Luca \& Volpin, Paolo, Corporate Governance Reforms in Continental Europe, 21 Journal of Economic Perspectives, 1, 117-140 (2007). Available at: https://papers. ssrn.com/sol3/papers.cfm?abstract_id=970796

FAma, Eugene F., Efficient Capital Markets: Reply, 31 The Journal of Finance, 1, 143145 (1976).

Finch, Vanessa, Pre-Packaged Administrations and the Construction of Propriety, 11 Journal of Corporate Law Studies, 1, 1-31 (2011).

Friedman, Ezra \& Wickelgren, Abraham L., A New Angle on Rules versus Standards, 16 American Law and Economics Review, 2, $499-549$ (2014).

Gelpern, Anna \& Gulati, Mitu, CDS Zombies, 13 European Business Organization Law Review, 347-390 (2012). Available at: http://scholarship.law.duke.edu/cgi/ viewcontent.cgi?article $=5336 \&$ context $=$ faculty_scholarship

Goddard, Robert, Excessive Remuneration and the Unfair Prejudice Remedy, 13 Edinburgh Law Review, 3, 517-519 (2009).

Hirschman, Albert Otтo, Exit, Voice, and Loyalty: Responses to Decline in Firms, Organizations, and States (Harvard University Press, Cambridge, 1970).

Hu, Henri T. C. \& Black, Bernard, Debt, Equity and Hybrid Decoupling: Governance and Systemic Risk Implications, 14 European Financial Management, 4, 663-709 (2008).

Jensen, Michael C. \& Meckling, William H., Theory of the Firm: Managerial Behavior, Agency Costs and Ownership Structure, 3 Journal of Financial Economics, 4, 305360 (1978). Available at: https://www2.bc.edu/thomas-chemmanur/phdfincorp/ MF891\%20papers/Jensen\%20and\%20Meckling\%201976.pdf

Johnson, Simon; Porta, Rafael La; LóPez-de-Silanes, Florencio \& Shleifer, Andrei, Tunneling, 90 American Economic Review, 2, 22-27 (2000). Available at: https:// scholar.harvard.edu/shleifer/publications/tunneling

Jung, Boochun; Lee, Woo-Jong \& Yang, Yanhua Sunny, The Impact of Dividend Covenants on Investment and Operating Performance, 43 Journal of Business Finance \& Accounting, 3-4, 414-447 (2016). 
Kaplow, Louis, Rules versus Standards: An Economic Analysis, 42 Duke Law Journal, 3, 557-629 (1992). Available at: http://scholarship.law.duke.edu/cgi/viewcontent. cgi? article $=3207 \&$ context $=\mathrm{dlj}$

Kershaw, David, Lost in Translation: Corporate Opportunities in Comparative Perspective, 25 Oxford Journal of Legal Studies, 4, 603-627 (2005).

Lele, Priya P. \& Siems, Mathias M., Shareholder Protection: A Leximetric Approach, 7 Journal of Corporate Law Studies, 1, 17-50 (2007).

Lim, Ernest, Directors' Fiduciary Duties: A New Analytical Framework, 129 Law Quarterly Review, 2, 242-263 (2013). Available at: https://papers.ssrn.com/sol3/ papers.cfm?abstract_id $=2368147$

McKnight, Andrew, Commitments to Lend in Troubled Times, 3 Law and Financial Markets Review, 2, 148-154 (2009).

Means, Benjamin, A Voice-Based Framework for Evaluating Claims of Minority Shareholder Oppression in the Close Corporation, 97 The Georgetown Law Journal, 1207-1256 (2009). Available at: http://scholarcommons.sc.edu/cgi/viewcontent. cgi?article $=1911 \&$ context=law_facpub

Mitnick, Barry M., Origin of the Theory of Agency: An Account by One of the Theory's Originators (March 25, 2013). Available at: http://ssrn.com/abstract=1020378

Porta, Rafael La; López-de-Silanes, Florencio \& Shleifer, Andrei, Corporate Ownership around the World, 54 The Journal of Finance, 2, 471-517 (1999).

Roberts, Michael R. \& Sufi, Amir, Renegotiation of Financial Contracts: Evidence from Private Credit Agreements, 93 Journal of Financial Economics, 159-184 (2009). Available at: http://finance.wharton.upenn.edu/ mrrobert/resources/ Publications/RenegotiationJFE2009.pdf

Schuster, Edmund Philipe, The Mandatory Bid Rule: Efficient, After All?, 76 Modern Law Review, 3, 529-563 (2013).

Shepherd, Johnna M.; Tung, Frederick \& Yoon, Albert H., What Else Matters for Corporate Governance?: The Case of Bank Monitoring, 88 Boston University Law Review, 4, 991-1041 (2008). Available at: http://www.bu.edu/law/journals-archive/ bulr/volume88n4/documents/yoon-whatelsematters.pdf

Smith, Clifford W. \& Warner, Jerold B., On Financial Contracting: An Analysis of Bond Covenants, 7 Journal of Financial Economics, 2, 117-161 (1979).

Triantis, Georges G., Secured Debt under Conditions of Imperfect Information, 21 The Journal of Legal Studies, 1, 225-258 (1992).

Triantis, Georges G. \& Daniels, Ronald J., The Role of Debt in Interactive Corporate Governance, 83 University of California Law Review, 4, 1073-1113 (1995). Available at: http://scholarship.law.berkeley.edu/cgi/viewcontent.cgi?article=1669\&contex $\mathrm{t}=$ californialawreview

Tung, Frederick, Leverage in the Board Room: The Unsung Influence of Private Lenders in Corporate Governance, 57 UCLA Law Review, 115-181 (2009). Available at: http://www.uclalawreview.org/pdf/57-1-3.pdf

Whitehead, Charles K., The Evolution of Debt: Covenants, the Credit Market, and Corporate Governance, 34 The Journal of Corporation Law, 3, 101-137 (2009). 
Available at: https://papers.ssrn.com/sol3/papers.cfm?abstract_id=1205222

Yadav, Yesha, The Case for a Market in Debt Governance, 67 Vanderbilt Law Review, 3, 771-835 (2014). Available at: https://papers.ssrn.com/sol3/papers.cfm?abstract_ id $=2225524$

Zinbarg, Edward D., The Private Placement Loan Agreement, 31 Financial Analysts Journal, 4, 33-35 (1975).

\section{Working papers}

ChefFins, Brian R., The Undermining of UK Corporate Governance (?) (University of Cambridge, Faculty of Law, Research Paper 4/2013 (2013). Available at: http:// ssrn.com/abstract=2129686, https://papers.ssrn.com/sol3/papers.cfm?abstract_id $=2129686 \& \mathrm{rec}=1 \& \mathrm{srcabs}=1953190 \& \mathrm{alg}=1 \&$ pos $=5$

Payne, Jennifer, Debt Restructuring in English Law: Lessons from the US and the Need for Reform (Oxford Legal Research Paper Series 89/2013, 13, 2014). Available at: http://ssrn.com/abstract $=2321615$

\section{Normativity}

United Kingdom, Civil Procedure Rules, Rule 31. Available at: https://www.justice.gov. uk/courts/procedure-rules/civil/rules/part31

United Kingdom, Companies Act 2006. Available at: http://www.legislation.gov.uk/ ukpga/2006/46/pdfs/ukpga_20060046_en.pdf

United Kingdom, Insolvency Act 1986. Available at: http://www.legislation.gov.uk/ ukpga/1986/45/pdfs/ukpga_19860045_en.pdf

\section{Jurisprudence, Legal cases}

England and Wales Court of Appeal, Bhullar v. Bhullar [2003] BCC 711 (Court of Appeal). Available at: http://www.bailii.org/ew/cases/EWCA/Civ/2003/424.html

England and Wales High Court of Justice, Wilkinson v. West Coast Capital [2005] EWHC 3009 (Chancery Division). Available at: http://lexisweb.co.uk/cases/2005/ december/wilkinson-v-west-coast-capital-and-others

Scotland, Court of Session, Outer House, Fowler v. Gruber [2009] CSOH 36. Available at: http://www.bailii.org/scot/cases/ScotCS/2009/2009CSOH36.html

United Kingdom, House of Lords, Aberdeen Railway Co. v. Blaikie (1854) 17 D (HL) 20.

United Kingdom, House of Lords, O’Neill v. Phillips [1999] UKHL 24. Available at: https://www.publications.parliament.uk/pa/ld199899/ldjudgmt/jd990520/neill01. $\mathrm{htm}$

United Kingdom, Court of Appeal, Re Barings PLC and others (No 5) [1999] 1 BCLC 433 (Chancery Division). Available at: http://swarb.co.uk/in-re-barings-plc-secretary- 
of-state-for-trade-and-industry-v-baker-no-5-chd-25-nov-1998/

\section{Others sources}

Loan Market Association, Single Currency Term and Revolving Facilities Agreement (LMA.STR08) 2014.

Obama, President Barack, Remarks of President Barack Obama (Address to Joint Session of Congress, February 24, 2009). Available at: https://obamawhitehouse. archives.gov/the-press-office/remarks-president-barack-obama-address-jointsession-congress

O’Neill, Neill, Sadly, Banks Are a Necessary Evil, The Mayo News [July 24, 2012]. Available at: http://www.mayonews.ie/comment-opinion/68-off-the-fence/15790sadly-banks-are-a-necessary-evil 